\title{
PENERAPAN MODEL PEMBELAJARAN TIME TOKEN TERHADAP PENINGKATKAN HASIL BELAJAR KONSEP CIRI-CIRI MAKHLUK HIDUP PADA SISWA KELAS VIII SMP KRISTEN YPKPM AMBON
}

\author{
Amelia Popla $^{1}$, Ine Arini ${ }^{2}$ \\ 1) Mahasiswa Pendidikan Biologi \\ 2) Dosen Program Pendidikan Biologi
}

\begin{abstract}
Background: Education is a business that is intentionally designed to achieve predetermined goals and provide certain knowledge, insights, skills and expertise to individuals to explore and develop talents and personalities.

Method: This study is a descriptive study that describes mastery learning using the Time Token learning model. The sample in this study was class VII2 students consisting of 34 students.

Results: This study shows that there is a significant influence by using the time token learning model towards improving student learning outcomes. At the time of the application of the time token learning model, it was seen that student learning outcomes were improved. Data obtained from the research results obtained with an average score reaching 54.70 and being in a failed qualification, while the final test 91.47 is in complete qualification.

Conclusion: The application of the time token learning model can improve the learning outcomes of the concept of living things in class VII2 YPKPM Christian Middle School Ambon by showing a significant success rate for students.
\end{abstract}

Keywords: Learning Model, time tokens, learning outcomes.

\begin{abstract}
Abstrak
Latar Belakang: Pendidikan adalah usaha yang sengaja dirancang untuk mencapai tujuan yang telah ditetapkan dan memberikan pengetahuan, wawasan, keterampilan, dan keahlian tertentu kepada individu-individu guna menggali dan mengembangkan bakat serta kepribadian. Metode: Penelitian ini adalah penelitian deskriptif yang menggambarkan ketuntasan belajar menggunakan model pembelajaran Time Token. Sampel dalam penelitian ini adalah siswa kelas $\mathrm{VII}^{2}$ yang terdiri dari 34 siswa.

Hasil: Penelitian ini menujukkan bahwa adanya pengaruh yang signifikan dengan menggunakan model pembelajaran time token terhadap peningkatan hasil belajar siswa. Pada saat penerapan model pembelajaran time token terlihat peningkatan hasil belajar siswa. Data hasil penelitan yang diperoleh dengan rata-rata skor pencapaian tes awal 54,70 dan berada pada kualifikasi gagal, sedangkan tes akhir 91,47 berada pada kualifikasi tuntas.

Kesimpulan: Penerapan model pembelajaran time token dapat meningkatkan hasil belajar konsep makhluk hidup pada siswa kelas VII ${ }^{2}$ SMP Kristen YPKPM Ambon dengan menunjukkan tingkat keberhasilan yang signifikan pada siswa.
\end{abstract}

Kata kunci : Model Pembelajaran, time token, hasil belajar. 


\section{PENDAHULUAN}

Visi pendidikan nasional adalah terwujudnya sistem pendidikan sebagai pranata yang kuat dan berwibawa untuk memberdayakan semua warga Negara Indonesia dan berkembang menjadi manusia yang berkualitas sehingga mampu dan proaktif dalam menjawab tantangan zaman yang selalu berubah lebih maju (Rusman, 2012). Pendidikan adalah usaha yang sengaja dirancang untuk mencapai tujuan yang telah ditetapkan dan memberikan pengetahuan, wawasan, keterampilan, dan keahlian tertentu kepada individuindividu guna menggali dan mengembangkan bakat serta kepribadian mereka (Sobri, 2013). Menurut Rustaman (2005), Sekolah sebagai penyelenggara pendidikan dapat menjamin kesesuaian proses yang dilaksanakan dengan kebutuhan manusia dimasa kini dan mendatang.

Proses pembelajaran tersusun atas sejumlah komponen atau unsur yang saling berkaitan satu dengan yang lainnya. Daya tarik suatu pelajaran dapat ditentukan oleh mata pelajaran itu sendiri dan cara guru mengajar. Penerapan strategi pembelajaran yang tepat dapat memotifasi siswa untuk giat belajar sehingga diperoleh hasil belajar yang optimal. Tercapainya ketuntasan hasil belajar siswa pada ranah kognitif, afektif, dan psikomotor merupakan indicator keberhasilan suatu pembelajaran (Suprihatiningrum, 2013).

Model pembelajaran Time Token merupakan salah satu model pembelajaran yang dirancang untuk mempengaruhi pola interaksi siswa. Pembelajaran Time Token juga merupakan salah satu model pembelajaran yang dapat digunakan untuk meningkatkan perolehan akademik dan untuk mengajarkan keterampilan sosial/kelompok, oleh karena itu siswa diharapkan bekerja saling membantu dalam kelompok kecil (Yumerisa, 2013).

Tujuan pembelajaran Time Token adalah timbulnya efek akademik yang dibarengi oleh efek pengiring seperti kemampuan bekerja sama, dan penghargaan terhadap eksistensi orang lain (Marhaeni, 2012). Tipe pembelajaran ini dimaksudkan sebagai alternative untuk mengajarkan keterampilan sosial yang bertujuan untuk menghindari siswa diam sama sekali dan menghendaki siswa saling membantu dalam kelompok. Keunggulan pendekatan Time Token yaitu mendorong siswa untuk meningkatkan inisiatif dan mencegah siswa diam sama sekali. Siswa menjadi aktif dalam kegiatan pembelajaran serta meningkatkan kemampuan siswa dalam berkomunikasi.

Aris (2010) menjelaskan bahwa pembelajaran time token adalah salah satu tipe pembelajaran kooperatif, siswa di bentuk dalam kelompok belajar yang pembelajaran ini mengerjakaan keterampilan sosial untuk menghindari siswa mendominasi pembicaran atau menghindarkan siswa diam sama sekali berdiskusi. Guru memberikan materi pembelajaran dan selanjutnya siswa bekerja dalam kelompok masing-masing untuk memastikan semua anggota kelompok teah menguasai materi pembelajran kemudia, siswa melakukan tes atas materi yang di berikan dan mereka harus mengerjakan sendiri tampa bantuan siswa lainnya. Menurut Slamento (2013) belajar merupakan suatu proses yang dilakukan oleh seseorang untuk memperoleh suatu perubahan tingkah laku yang baru secara keseluruhan sebagai hasil dari interaksi dirinya dengan lingkungan dimana dia berada.

Model pembelajaran time token adalah salah satu rancangan konseptual yang dapat digunakan untuk mengajarkan ketrampilan sosial dan menghindari siswa mendominasi pembicaraan atau menghindarkan siswa diam sama sekali dalam berdiskusi. Dalam proses pembelajaran siswa akan lebih memberi perhatian yang ekstra menggunakan makna dari materi pembelajaran tesebut sehingga dapat meninggkatkan hasil belajar siswa. Miler dan Peterson (2010) mengatakan bahwa, metode Time Token di harapakan dapat meningkatkan partisipasi seluruh siswa.

Tujuan utama dari Time Token adalah untuk mengatasi hambatan pemeratan kesempatan yang sering mewarnai kerja kelompok. Pembelajaran dengan teknik ini 
di laksanakan dengan cara membagikan kartu untuk seluruh siswa dan setiap kali berbicara baik dalam kerja sama kelompok maupun klasikal harus menyerahkan kartu. Bagi siswa yang sudah habis kartunya tidak di perkenankan berbicara lagi, sehingga di harapkan seluruh siswa akan mempunyai keterlibatan atau partisipasi yang berimbang yang berkaitan pada pemahaman yang lebih baik (Wiyasri, 2010).

Jadi salah satu alternative untuk memecahkan masalah tersebut di atas adalah dengan menggunakan strategi model pembelajaran Time Token karena melihat adanya keterkaitan antara mata pelajaran Biologi tentang ciri-ciri makhluk hidup. materi pembelajaran ciri-ciri makhluk hidup ini adalah, ovivar dengan cara bertelur,

Tipe penelitian yang digunakan dalam penelitian ini adalah penelitian Deskriptif yang menggambarkan ketuntasan belajar menggunakan model pembelajaran Time Token. Sampel dalam penelitian ini adalah siswa kelas $\mathrm{VII}^{2}$ yang terdiri dari 34 siswa. Variabel yang digunakan dalam penelitian ini adalah:

1. Variabel bebas yaitu penerapan model pembelajaran Time Token

2. Variabel terikat yaitu peningkatan hasil belajar

Instrumen penelitian yang digunakan adalah sebagai berikut:

1. Tes; tes digunakan untuk tes awal dan tes formatif yang masing-masing berisi 10 soal pilihan ganda dan lembar kerja siswa (LKS) untuk menilai aspek kognitif siswa.

2. Non Tes; non tes berupa lembaran observasi untuk menilai aspek afektif dan psikomotor.

Teknik pengumpulan data dalam penelitian ini diperoleh melalui tes awal dan tes formatif, dan observasi untuk mengamati kemampuan afektif dan psikomotor. Data kemampuan kognitif diperoleh lewat hasil LKS.

Teknik Analisis data dalam penelitian ini akan dianalisis secara deskriptif. Analisis contohnya ikan mengeluarkan telur saat pemijahan . vivivar dengan cara melahirkan, contohnya kandungan kuning telur sangat sedikit dan perkembangan embrio di tentukan hubungan dengan placenta pada tahap awal untuk mencukupi kebutuhan makanannya. Dan ovovivivar bertelur dan beranak hewan tersebut bertelur dan menetas di dalam tubuh hewan. Dengan model pembelajaran Time Token karena lebih berpusat pada keaktifan siswa dimana masing-masing siswa mendapatkan kartu berbicara hingga siswa lebih aktif dan lebih mempersiapkan diri ketika berbicara didepan.

\section{MATERIAL DAN METODE}

deskriptif dilakukan dengan langkahlangkah sebagai berikut :

a. Skor pencapaian (SP) atau nilai (N) hasil tes awal , tes akhir kemampuan afektif tiap tatap muka, kemampuan psikomotor, kemampuan kognitif tatap muka, kemampuan kognitif tiap LKS diperoleh dengan cara :

$\mathrm{SP}=\frac{\text { Skor perolehan }}{\text { Skor maksimum }} \times 100 \%$

Selanjutnya Nilai proses (NP) diperoleh dengan cara:

$\mathrm{N}=\frac{\text { N.Kognitif }+N . \text { Afektif }+N . \text { Psikomotor }}{3}$

Setelah memperoleh nilai dari tiap aspek, maka selanjutnya nilai tersebut dihitung untuk memperoleh nilai akhir denga rumus:

$$
\mathrm{NA}=\frac{6 P+4 p}{10}
$$

Keterangan :

NA : Nilai Akhir

$P \quad$ : Nilai Proses

F : Nilai hasil tes formatif setelah proses pembelajaran

Setiap siswa dikatakan telah tuntas belajar (kompeten) pada materi ini jikanilai akhirnya telah memenuhi KKM yakni 75 , dan untuk kualifikasi ketuntasan siswa, setiap nilai akhir siswa dikonsultasikan dengan mengacu pada tabel 1. 
Tabel 1. Interval Skor Pencapaian Kompetensi

\begin{tabular}{cc}
\hline Interval Skor Pencapaian & Kualifikasi \\
\hline $91-100 \%$ & Sangat Baik \\
$86-90 \%$ & Baik \\
$76-85 \%$ & Cukup \\
$\leq 75 \%$ & Gagal \\
\hline
\end{tabular}

Keterangan: Jika siswa memiliki nilai $\geq 75$ dapat dikategorikan berhasil atau tuntas pada aspek kognitif,afektif dan psikomotor sedangkan jika siswa memiliki nilai $\leq 75$ dapat dikategorikan tidak berhasil (tidak tuntas) pada aspek kognitif, afektif dan psikomotor.

HASIL DAN PEMBAHASAN

Deskripsi Penguasaan Tes Awal (Pretest)

Hasil tes awal menunjukkan kemampuan awal siswa sebelum mengikuti proses belajar mengajar (KBM) materi ciriciri makhluk hidup dengan menerapkan
Hasil

Model pembelajaran Time Token. Kualifikasi rata-rata skor pencapaian siswa pada tes awal terdapat pada tabel 2 yang menunjukan bahwa kemampuan awal siswa sangat rendah. Hal ini terbukti dengan 34 siswa $(100 \%)$ berada pada kategori gagal.

Tabel 2. Kualifikasi Skor Pencapaian Siswa Pada Tes Awal

\begin{tabular}{cccc}
\hline Interval & Frekuensi & Presentase & Kualifikasi \\
\hline$\geq 75$ & - & - & Tuntas \\
$\leq 75$ & 34 & $100 \%$ & Gagal \\
Jumlah & 34 & $100 \%$ & - \\
\hline
\end{tabular}

Pada tabel 2 terlihat pencapaian siswa pada tes awal, dimana pada interval $\geq 75$ tidak ada siswa yang memiliki nilai kualifikasi tuntas, dan pada interval $\leq 75$ terdapat 34 siswa (100\%) berada pada kualifikasi gagal yang belum mampu menguasai indikator-indikator pembelajaran yang akan dipelajari sehingga dikatakan ketuntasan belajar klasikal maupun individual belum tercapai dengan rata-rata skor pencapaian 54,70 .

\section{Deskripsi Tingkat Penguasaan Siswa Selama Proses Pembelajaran Kemampuan Kognitif Siswa}

Data kemampuan kognitif siswa selama proses pembelajaran dengan menerapkan model pembelajaran Time Token dapat dilihat melalui presentase LKS. Kualifikasi rata-rata skor pencapaian siswa pada LKS terlihat pada tabel 3.

\section{Tabel 3. Kualifikasi Hasil Belajar Siswa Pada Aspek Kogntif}

\begin{tabular}{cccc}
\hline Interval & Frekuensi & Presentase & Kualifikasi \\
\hline$\geq 75$ & 34 & $100 \%$ & Tuntas \\
$\leq 75$ & - & - & Gagal \\
Jumlah & 34 & $100 \%$ & - \\
\hline
\end{tabular}

Pada tabel 3 menunjukan hasil pencapaian siswa pada aspek kognitif dimana pada interval $\geq 75$ terdapat 34 siswa $(100 \%)$ yang memiliki nilai dengan kualifikasi tuntas, dan pada interval $\leq 75$ tidak terdapat siswa pada posisi dengan kualifikasi gagal, jika dibandingkan dengan rata-rata skor pencapaian siswa pada aspek kognitif, maka dapat dikatakan pencapaian kognitif siswa berada pada kualifikasi tuntas dengan rata-rata skor pencapaian adalah 90,36.

\section{Kemampuan Afektif Siswa}

Data mengenai kemampuan afektif siswa selama proses pembelajaran dengan menerapkan model pembelajaran Resource Based Learning ditujukan kepada nilai unjuk 
kerja selama proses pembelajaran. Kualifikasi rata-rata skor pencapaian siswa pada aspek afektif dapat terlihat pada tabel 4.

Tabel 4. Kualifikasi Hasil Belajar Siswa Pada Aspek Afektif

\begin{tabular}{cccc}
\hline Interval & Frekuensi & Presentase & Kualifikasi \\
\hline$\geq 75$ & 34 & $100 \%$ & Tuntas \\
$\leq 75$ & - & - & Gagal \\
Jumlah & 34 & $100 \%$ & - \\
\hline
\end{tabular}

Berdasarkan tabel 4. terlihat hasil pencapaian siswa pada aspek afektif, dimana pada interval $\geq 75$ siswa $(100 \%)$ memiliki nilai dengan kualifikasi tuntas, dan pada interval $\leq 75$ tidak terdapat siswa dengan kualifikasi gagal. Jika dibandingkan antar nilai KKM dengan rata-rata skor pencapaian siswa pada aspek afektif, maka dapat dikatakan pencapaian afektif siswa berada pada kualifikasi tuntas dengan ratarata skor pencapaian 88,71 .

\section{Kemampuan Psikomotor Siswa}

Data mengenai kemampuan psikomotor siswa selama proses pembelajaran dengan menerapkan model Resource Time Token menunjukan ratarata skor pencapaian siswa dalam penilaian proses aspek psikomotor. Kualifikasi ratarata skor pencapaian siswa dapat dilihat pada tabel 5.

Tabel 5. Kualifikasi Hasil Belajar Siswa Pada Aspek Psikomotor

\begin{tabular}{cccc}
\hline Interval & Frekuensi & Presentase & Kualifikasi \\
\hline$\geq 75$ & 34 & $100 \%$ & Tuntas \\
$\leq 75$ & - & - & Gagal \\
Jumlah & 34 & $100 \%$ & - \\
\hline
\end{tabular}

Berdasarkan tabel 5 terlihat hasil pencapaian siswa pada aspek psikomotor, dimana pada interval $\geq 75$ terdapat 34 siswa $(100 \%)$ yang memiliki nilai ini, dengan kualifikasi tuntas, dan pada $\leq 75$ posisi ini, dengan kualifikasi gagal. Jika dibandingkan antara nilai KKM dengan rata-rata skor pencapaian siswa pada aspek psikomotor, maka dapat dikatakan pencapaian psikomotor siswa berada pada kualifikasi tuntas dengan rata-rata skor pencapaian adalah 93,59.

\section{Dekripsi Tes Formatif (Post-Test)}

Data mengenai hasil skor pencapaian siswa dalam tes formatif yang dilaksanakan setelah kegiatan belajar mengajar dengan menerapkan model pembelajaran Time Token dapat di lihat pada tabel 6 .

Tabel 6. Kualifikasi Hasil Belajar Siswa Pada Tes Formatif

\begin{tabular}{cccc}
\hline Interval & Frekuensi & Presentase & Kualifikasi \\
\hline$\geq 75$ & 34 & $100 \%$ & Tuntas \\
$\leq 75$ & - & - & Gagal \\
Jumlah & 34 & $100 \%$ & - \\
\hline
\end{tabular}

Berdasarkan tabel 6 dapat terlihat hasil pencapaian siswa pada tes formatif, dimana pada interval $\geq 75$ terdapat 34 siswa $(100 \%)$ memiliki nilai dengan kualifikasi tuntas, dan pada interval $\leq$ tidak terdapat siswa pada posisi ini, dengan kualifikasi gagal. Jika dibandingkan antar nilai KKM dengan rata- rata skor pencapaian siswa pada tes formatif, maka dapat dikatakan pencapaian kemampuan siswa pada kategori tuntas dengan rata-rata 91,47 . 


\section{Deskripsi Nilai Akhir Siswa}

Setelah dilakukan pembelajaran dengan menerapkan model Time Token pada materi makhluk hidup, pencapaian nilai akhir (NA) p menggambarkan tingkat pencapaian pada tes formatif dapat dilihat pada tabel 7.

Tabel 7. Kualifikasi Hasil Belajar Siswa Pada Nilai Akhir

\begin{tabular}{cccc}
\hline Interval & Frekuensi & Presentase & Kualifikasi \\
\hline$\geq 75$ & 34 & $100 \%$ & Tuntas \\
$\leq 75$ & - & - & Gagal \\
Jumlah & 34 & $100 \%$ & - \\
\hline
\end{tabular}

Berdasarkan tabel 7 terlihat hasil pencapaian siswa pada nilai akhir, dimana pada interval $\geq 75$ terdapat 34 siswa $(100 \%)$ yang memiliki nilai ini dengan kualifikasi tuntas, dan pada interval $\leq 75$ tidak terdapat siswa pada posisi dengan kualifikasi gagal. Jika dibandingkan antara nilai KKM dengan rata-rata skor pencapaian adalah 88,19.

\section{Pembahasan}

\section{Penerapan Model Time Token Terhadap Peningkatkan Hasil Belajar}

Berdasarkan hasil penelitian yang di peroleh pada siswa kelas $\mathrm{VII}^{2}$ SMP Kristen YPKPM Ambon,sebelum melakukan kegiatan belajar mengajar (KBM) siswa diberikan tes awal (pre-test), tabel 2 terlihat hasil pencapaian siswa pada tes awal, dimana pada interval $\leq 75$ terdapat 34 siswa $(100 \%)$ berada pada kualifikasi gagal dengan rata-rata skor pencapaian 54,70. Tes ini dilakukan dengan tujuan untuk mengetahui tingkat penguasaan siswa terhadap konsep yang diterima sebelumnya. Peningkatan terhadap hasil belajar perlu adanya model yang dapat mendukung proses pembelajaran, maka peneliti menerapkan suatu model yakni, model pembelajaran Time Token.

Model Time Token memiliki langkahlangkah pembelajaran dengan sebutan menjelaskan tujuan pembelajaran/KD, mengkondisikan kelas, memberikakan tugas, membagikan dan meminta kembali kupon berbicara dan memiliki kelebihan yang dapat meningkatkan kemampuan siswa dalam berkomunikasi serta meningkatkan hasil belajar siswa secara tepat dan benar. Menerapkan model dalam proses pembelajaran pada tabel 3 menggambarkan aspek kognitif siswa di lihat dari hasil belajar pada lembar kerja, pencapaian LKS terlihat bahwa sebanyak 34 siswa (100\%) orang siswa berada pada interval $\geq 75$ dengan rata-rata 90,36 , tabel 4 terlihat hasil pencapaian siswa pada aspek afektif, dimana pada interval $\geq 75$ terdapat 34 siswa (100\%) yang memliki nilai ini dengan kualifikasi tuntas dengan rata-rata skor pencapaian adalah 88,71.

Pada aspek kognitif yang di nilai adalah teliti dalam mengerjakan LKS, kerja sama dalam dalam kelompok dan kedisiplinan dalam kelompok. Pada tabel 5 terlihat hasil pencapaian siswa pada aspek psikomotor, dimana ada interval $\geq 75$ terdapat 34 siswa $(100 \%)$ yang memiliki nilai ini dengan kualifikasi tuntas dengan rata-rata skor pencapaian adalah 93,59. Pada aspek psikomotor yang dinilai adalah kompetensi menyampaikan pertanyaan, kompetensi menjawab pertanyaan, dan kompetensi membuat kesimpulan. Setelah melakukan proses belajar mengajar (PBM) dengan menerapkan model pembelajaran Time Token dalam pembelajaran biologi pada pertemuan I,II dapat di lihat bahwa ada peningkatan jumlah siswa yang mendapatkan nilai $\mathrm{KKM} \geq 75$ terdapat 34 siswa $(100 \%)$ yang memiliki nilai ini dengan kualifikasi Tuntas, dengan rata-rata skor pencapaian secara klasikal yaitu 88,19.

Dengan demikian penerapan model Time Token sangat berperan penting dalam proses belajar mengajar karena hasil belajar siswa tercapai secara keseluruhan dengan baik. Hasil belajar adalah seluruh percakapan hasil (achievement) yang diperoleh melalui belajar disekolah, yang dinyatakan dengan nilai - nilai prestasi belajar berdasarkan hasil tes belajar (Darsono, 2000). 


\section{KESIMPULAN}

Dari hasil data pembahasan mengenai hasil penelitian dapat di ambil kesimpulan bahwa penerapan model pembelajaran Time Token terhadap peningkatkan hasil belajar konsep makhluk hidup pada siswa kelas $\mathrm{VII}^{2}$ SMP Kristen YPKPM Ambon menunjukan tingkat keberhasilan yang signifikan. Hasil tes awal siswa rata-rata pencapian $54,70 \%$ dan dikatakan belum tuntas. sementara pada aspek kognitif, afektif, psikomotor, tes akhir dan nilai akhir rata-rata presentase pencapaian skor $88,19 \%$ dan dikategorikan berhasil.

\section{DAFTAR PUSTAKA}

Aris. Shoimin. 2010. "Pembelajaran, Pengajaran dan Asesmen". Yogyakarta: Pustaka Belajar

Darsono, M. 2000. "Belajar dan Pembelajaran". Semarang : IKIP Semarang Press

Marhaeni, A.A.I.N. 2012. "Landasan dan Inovasi Pembelajaran”. Singaraja: Universitas Pendidikan Ganesha.
Miller, Peterson. 2010. "Pembelajaran Koperatif”. Surabaya : University Press UNESA

Rusman.2012. "Model - model Pembelajaran”. Jakarta: Raja Grafindo Persada.

Rustaman, Nuryani. 2005. "Strategi Belajar Mengajar Biologi". Malang : IKIP Malang

Sobri,M. Sutikno.2013. "Belajar dan pembelajaran". Lombok: Holistika.

Slamento. 2013. "Belajar dan faktor faktor yang mempengaruhinya". Jakarta: PT rineka Cipta.

Suprihatiningrum, Jamil. 2013. "Strategi Pembelajaran". Yogyakarta: AR-RUZZ MEDIA.

Wiyarsi, Antumi. 2010. "Implementation Of Coperative Learning Type Time Token to Increase the Students Activity and Interest Learning on General Chemistry". Jurnal Pendidikan Kimia. Yogyakarta: Universitas Negeri Yogyakarta.

Yumerisa. 2013. Pengembangan System Pendidikan di Indonesia, Bandung: CV Pustaka 